\title{
PENDIDIKAN ISLAM DALAM PERSPEKTIF MASYARAKAT PETANI MADURA
}

\author{
Usman \\ (IAIN Madura)
}

\begin{abstract}
Abstrak:
Artikel ini memaparkan pandangan masyarakat petani di Pamekasan Madura tentang pendidikan Islam sebagai realitas sosial yang terkonstruksi. Para petani menganggap bahwa pendidikan Islam wajib dipelajari oleh anak-anak mereka sebagai bekal penanaman akhlak bagi kehidupan di masa depan. Mereka lebih mementingkan ketercapaian kualitas akhlak anak-anak mereka daripada memikirkan profesi yang akan mereka pilih. Hal ini menandakan bahwa konstruksi sosial suatu masyarakat memiliki ciri khas tersendiri bagi pertumbuhan dan perkembangan pendidikan anak pada setiap fasenya. Hasil penelitian di lapangan menunjukkan bahwa pola asuh berbasis nilai-nilai spiritual, sikap positif lingkungan, dan penerimaan masyarakat terhadap keberadaan anak akan menumbuhkan konsep diri yang berimplikasi pada pembentukan akhlak positif pada diri anak.
\end{abstract}

Kata Kunci: Pendidikan Islam; Petani; Pola Asuh Anak.

\begin{abstract}
:
This article explores perspectives of peasant community in Pamekasan Regency Madura regarding Islamic education as constructed reality. The peasants consider the obligatory of pursuing such education for their children's Islamic morality in their future. They put first priority in the Islamic education rather than hustling about what profession their children are going to have. This indicates that social construction in a community has uniqueness for the development of child education in every phase. Findings show that spiritual-based parenting, environment positive attitude, and community acceptance to the children develop concept of self, which has implication to the development of children Islamic morality.
\end{abstract}

\section{Keywords: Islamic Education; Peasant; Parenting.}




\section{A. Pendahuluan}

Pendidikan Islam secara normatif sarat dengan nilai-nilai transendental baik yang menyangkut persoalan Ilahiah maupun insaniah. ${ }^{1}$ Proses pendidikan Islam harus berlangsung secara kontekstual dengan nilai-nilai. Karena Islam sebagai agama wahyu mengandung sistem nilai yang menjadi pedoman hidup umat manusia dalam segala bidang, termasuk pendidikan. Umat manusia dalam kehidupannya (secara individu maupun sosial), selalu dipengaruhi oleh sistem nilai, baik nilai kultural maupun nilai keagamaan. Sistem nilai yang bersumber pada kultur bersifat relatif, sedangkan sistem nilai agama bersifat absolut, tidak dinamis mengikuti selera budaya manusia.

Setiap proses dalam pendidikan harus dilakukan secara sadar dan memiliki tujuan. Tujuan pendidikan secara umum adalah mewujudkan perubahan positif yang diharapkan ada pada anak didik setelah menjalani proses pendidikan, baik perubahan pada tingkah laku individu, kehidupan pribadinya maupun kehidupan masyarakat dan alam sekitarnya. Tujuan pendidikan merupakan masalah inti dalam pendidikan dan saripati dari seluruh renungan pedagogik. Belajar atau bersekolah sama-sama bermakna mencari ilmu yang merupakan bagian penting dari proses pendidikan yang pada intinya adalah transfer ilmu dan nilai moral. Pendidikan dalam konteks ini terkait dengan gerak dinamis, positif dan kontinu setiap individu menuju idealitas kehidupan manusia agar mendapatkan nilai terpuji. Aktivitas individu tersebut meliputi pengembangan kecerdasan pikir (rasio, kognitif), dzikir (afektif, rasa, hati, spiritual) dan keterampilan fisik (psikomotorik). ${ }^{2}$

Pada dasarnya, pendidikan dilakukan pertama kali oleh keluarga, terutama orang tua terhadap anak-anaknya. ${ }^{3}$ Oleh karena keterbatasan waktu dan fasilitas yang dimiliki orang tua, akhirnya pendidikan anak diserahkan pada lembaga pendidikan untuk mengatasi keterbatasan tersebut. Meskipun demikian setiap orang memiliki pandangan atau pemahaman yang berbeda mengenai pendidikan Islam berdasarkan latarbelakang kehidupannya.

Pada hakikatnya, pendidikan Islam adalah proses perubahan menuju ke arah yang positif. Dalam konteks sejarah, perubahan yang positif ini adalah jalan Tuhan yang telah dilaksanakan sejak zaman Nabi Muhammad saw. Pendidikan Islam dalam konteks perubahan ke arah yang positif ini identik dengan kegiatan dakwah yang biasanya dipahami sebagai upaya untuk menyampaikan ajaran

${ }^{1}$ Achmadi, Ideologi Pendidikan Islam: Paradigma Humanisme Teosentris (Yogyakarta: Pustaka Pelajar, 2010), 1.

2 Moh. Roqib, Ilmu Pendidikan Islam: Pengembangan Pendidikan Integratif di Sekolah, Keluarga dan Masyarakat (Yogyakarta: LKiS, 2009), 14.

3 Nurul Salma, "Makna Pendidikan Anak bagi Masyarakat Petani di Desa Munggu Kecamatan Petanahan Kabupaten Kebumen”, Jurnal Kebijakan Pendidikan, Edisi 5 Vol. 5 (2016). 
Islam kepada masyarakat pada seluruh lapisannya, mulai dari kaum cendekian sampai pada kaum petani.

Terkhusus kaum petani, modal utama dan tumpuan pokok bagi kehidupan petani pedesaan Jawa Timur adalah sawah. Pertanian sawah memungkinkan adanya penyerapan tenaga kerja yang besar. Meski sistem pertanian ini memberikan hasil minim bagi petani, tetapi ia memberikan elastisitas, sehingga sawah menjamin bagi mata pencaharian masyarakat dan terhindar dari degradasi lingkungan. Dilihat dari aspek historis lahan pertanian di sawah sebenarnya telah mengalami perubahan positif dengan tantangan yang tidak begitu berat jika dibandingkan dengan pertanian pegunungan (seperti salah satunya yang terjadi di Tengger). Karena, para petani di daerah pegunungan harus beradaptasi tidak saja bagi populasi penduduk dan perubahan politik serta ekonomi, tetapi juga terhadap konsekuensi ekologis yang tidak mengenakkan. Konsekuensi ekologis dapat dikatakan hampir tidak pernah terjadi di daerah berlahan sawah, karena sistem irigasi yang memadai. 4

Deskripsi di atas sesuai dengan realitas yang terjadi di Pamekasan Madura khususnya di daerah pesisir, dataran rendah dan dataran tinggi, mengenai pemahamannya terhadap pendidikan Islam. Dalam hal ini, petani memiliki motivasi tersendiri untuk memperhatikan pendidikan anak-anaknya. Salah satu alasan mereka menginginkan anak-anak mereka sekolah di lembaga pendidikan Islam (khususnya ke jenjang yang semakin tinggi) adalah agar nasibnya tidak sama dengan orang tua mereka dan tidak ingin anaknya merasakan sengsara, sehingga orang tua mereka yakin bahwa jalan satu-satunya untuk merubah nasib salah satunya melalui pendidikan. Anak merupakan harapan orang tua, karena sebagai harapan maka orang tua menginginkan anaknya menempuh pendidikan setinggi mungkin agar statusnya tidak sama dengan dirinya. Di sisi lain, orang tua juga menginginkan anaknya memiliki kehidupan yang lebih baik dan agar generasi mereka lebih baik dari mereka, utamanya dalam keilmuan dengan harapan terbentuk generasi yang berguna bagi nusa, bangsa dan agama.

Adapun pendapat dari salah satu warga petani bahwa "saya memakai sandal, masak anak saya juga memakai sandal?". Jadi, pendidikan sangat penting bagi mereka karena mereka menginginkan anaknya lebih dari mereka dan menginginkan anak-anak mereka tidak merasa tertinggal dengan perkembangan keilmuan dan teknologi. Bahkan agar memudahkan anak-anak mereka dalam mencari kerja dan menjadi orang yang berilmu yang bisa dibanggakan oleh keluarganya. Di samping itu, para petani di Pamekasan memiliki perbedaan motivasi mengenai pendidikan bagi anak mereka. Perbedaan motivasi inilah yang

${ }^{4}$ Fatchan dan Basrowi, Pembelotan Kaum Pesantren dan Petani di Jawa (Surabaya: Yayasan Kampusina, 2004), 78. 
memungkinkan petani memiliki perbedaan persepsi dan rencana studi bagi anak mereka.

Realitas yang tergambar di Kabupaten Pamekasan Madura adalah bahwa tidak semua keinginan petani untuk memfasilitasi pendidikan anaknya tercapai. Ada beberapa alasan, misalnya karena tidak mempunyai biaya, kurangnya semangat dalam diri para orang tua dan anak untuk melanjutkan pendidikan, sehingga dengan keadaan seperti itu sumber daya manusia yang dimiliki oleh keluarga itu tetap rendah dan tetap berada dalam kehidupan kurang sejahtera. Tetapi pemerintah mempunyai berbagai macam program untuk mengatasi hal tersebut, seperti program bantuan Kartu Indonesia Pintar, Kartu Indonesia Sehat, dan lain sebagainya yang semuanya adalah untuk menciptakan sumber daya manusia warga Indonesia, khususnya para anak dari keluarga yang tidak mampu menjadi lebih baik.

Oleh karena itu, peneliti tertarik dan ingin mengetahui lebih dalam tentang bagaimana pendidikan Islam dalam perspektif petani - yang dianggap sebagai masyarakat kelas bawah - di daerah Pamekasan Madura, khususnya bagi petani garam di pesisir, petani padi di dataran rendah, dan petani tembakau di dataran tinggi. Dari persepsi tersebut akan membentuk sebuah konstruksi sosial terkait pendidikan Islam di Pamekasan. Sehingga kerangka tersebut akan dikaji dari berbagai aspek dalam kehidupan, baik aspek ekonomi, sosial, dan agama.

\section{B. Pendidikan Islam sebagai Fondasi}

Dalam istilah Arab, ada tiga istilah yang dipakai untuk menyebut pendidikan, yaitu tarbiyyah, ta'lim, dan ta'dib. ${ }^{5}$ Pertama, tarbiyah berarti berkembang, tumbuh dan menjadi besar atau dewasa, memperbaiki, memelihara, memperindah, mengasuh, mengatur dan menjaga kelestariannya dan eksistensinya. Dengan kata lain, tarbiyyah memiliki definisi sebagai upaya mempersiapkan individu untuk mencapai kehidupan yang bahagia dan sempurna. Kedua ta'lim, yaitu suatu proses belajar yang hanya sebatas transfer of knowledge, bagaimana peserta didik dapat menguasai nilai yang telah ditransfer secara kognitif. Ketiga ta'dib, yaitu proses mendidik yang lebih tertuju pada pembentukan dan pembinaan serta penyempurnaan akhlak atau budi pekerti bagi peserta didik. 6

Dari ketiga istilah pendidikan dalam konteks Islam di atas yang paling cocok untuk diterapkan dalam kegiatan pendidikan keagamaan atau pendidikan Islam yaitu pada tipe ketiga yakni ta'dib, karena terfokus pada proses pembentukan dan pembinaan serta penyempurnaan akhlak atau budi pekerti bagi peserta didik, berbeda dengan tarbiyah yang merupakan tipe pendidikan yang

\footnotetext{
${ }^{5}$ Siswanto, Filsafat dan Pemikiran Pendidikan Islam (Surabaya: Pena Salsabila, 2015), 11.

${ }^{6}$ Jalaluddin, Teologi Pendidikan (Jakarta: Raja Grafindo Persada, 2003), 73.
} 
masih secara umum, sedangkan ta'lim yang lebih pada transfer ilmu pengetahuan dalam proses pembelajarannya.

Dengan demikian pendidikan merupakan upaya sadar yang dilakukan oleh seorang pendidik untuk menjadikan seorang peserta didik yang tidak bisa menjadi bisa, tidak tahu menjadi tahu, dan memiliki perubahan sikap yang semula tidak baik menjadi lebih baik melalui proses belajar mengajar. Sehingga terjadi proses pengubahan sikap dan tata laku seseorang atau kelompok orang dalam usaha mendewasakan manusia melalui upaya pengajaran dan pelatihan, proses, cara serta aktivitas mendidik.

Sedangkan Islam yaitu nama salah satu agama yang dibawa oleh Nabi Muhammad saw. yang datang dari Allah swt. yang ajaran-ajarannya bersumber dari wahyu al-Qur'an dan Sunnah. Islam sebagai ajaran yang datang dari Allah sesungguhnya merefleksikan nilai-nilai pendidikan yang mampu membimbing dan mengarahkan manusia sehingga menjadi manusia sempurna. ${ }^{7}$ Karena menjadi manusia sempurna memerlukan proses yang cukup panjang dan membutuhkan keseriusan dan keistiqamahan dalam menjalankannya.

Dari dua definisi di atas, Hasan Langgulung dalam Sutrisno dan Albarobis menyatakan bahwa pendidikan Islam adalah suatu proses penyiapan generasi muda untuk mengisi peranan memindahkan pengetahuan dan nilai-nilai Islam yang diselaraskan dengan fungsi manusia untuk beramal dan memetik hasilnya di akhirat.8 Artinya, pendidikan Islam tidak bisa dimaknai sebatas transfer of knowldge, akan tetapi juga transfer of value serta berorientasi dunia akhirat (teosentris dan antroposentris).

Oleh karena itu, hal yang perlu ditekankan ialah hal yang paling mendasar yang terkait dengan aspek ruhani, yaitu keimanan (tauhid). Oleh karenanya, penulis menyimpulkan definisi pendidikan Islam sebagai usaha sadar untuk membimbing indivdu menjadi pribadi beriman yang kuat secara fisik, mental dan spiritual serta cerdas, berakhlak mulia dan memiliki keterampilan yang diperlukan bagi kebermanfaatan dirinya, masyarakatnya dan lingkungannya.

Dasar pendidikan Islam adalah tauhid. Konsep tauhid menjadi tema yang sangat penting dalam pandangan Islam serta mengandung implikasi doktrinal yang berkaitan dengan tujuan hidup manusia haruslah dalam kerangka beribadah kepada Allah swt. Dokrin ini merupakan kunci dari seluruh ajaran Islam. Dari konsep tauhid inilah akan muncul standar yang sangat penting dalam konsep pendidikan Islam, yaitu satandar akhlak (baca: standar nilai), yang esensinya adalah baik-buruk.

7 Beni Ahmad Saebani dan Hendra Akhdiyat, Ilmu Pendidikan Islam (Bandung: Pustaka Setia, 2012), 22.

8 Sutrisno dan Muhyidin Albarobis, Pendidikan Islam Berbasis Problem Sosial (Jogjakarta: ArRuzz Media, 2012), 21. 
Konsep pendidikan berbasis tauhid ini sesungguhnya sudah diajarkan oleh Allah, melalui seorang ahli hikmah yang namanya diabadikan sebagai salah satu nama surah dalam al-Qur'an, yaitu Luqman. Konsep pendidikan perspektif Luqman ialah menjadikan keimanan kepada Allah (tauhid) sebagai pelajaran pertama. Hal ini termaktub dalam QS. Luqman ayat $13 .{ }^{9}$

Ayat tersebut menegaskan bahwa tauhid atau akidah sebagai basis pendidikan. Tauhid dijadikan sebagai fondasi atau dasar, sebab dari tauhid itulah aspek-aspek lain (ibadah dan akhlak) dilahirkan. Sedangkan dalam ayat-ayat berikutnya, barulah Luqman memberikan pelajaran akhlak dan ibadah kepada anaknya, seperti perintah untuk berbakti kepada orang tua, larangan untuk tidak sombong, perintah mendirikan shalat dan sebagainya. Dalam al-Qur'an, Allah membuat tamsil yang sangat indah mengenai ketiga aspek (akidah-ibadahakhlak).

Sedangkan tujuan pendidikan Islam sesungguhnya tidak bisa lepas dari diskusi tentang tujuan hidup manusia. Sebab tujuan pendidikan yang paling ideal seharusnya bermuara pada pembentukan manusia yang ideal.Sementara sosok manusia yang ideal tentu manusia yang tujuan hidupnya telah selaras dengan tujuan penciptanya. Dilihat dari firman Allah swt. setidaknya ada empat tujuan hidup manusia, yaitu: Pertama, untuk mengabdi/beribadah kepada Allah, sebagaimana difirmankan dalam al-Qur'an surat Al-Dzariyat: 56.10 Kedua, untuk menjadi khalifah Allah di bumi, sebagaimana firman Allah dalam surat Al-Baqarah: 30. ${ }^{11}$ Ketiga, untuk mendapatkan ridha Allah swt, sebagaimana firman-Nya dalam surat Al-Taubah: 100). ${ }^{12}$ Keempat, untuk meraih kebahagiaan hidup dunia dan akhirat, sebagaimana termaktub dalam al-Qur'an surat Al-Baqarah: 201-202.13 Maka, pendidikan Islam harus dikembalikan ke khitahnya sebagaimana telah diteladankan oleh Rasulullah dan para penerusnya dari generasi terbaik. Untuk apa sesungguhnya pendidikan dalam pespektif Islam dilakukan? Inilah pertanyaan mendasar dan substansi dari pertanyaan ini adalah tentang tujuan pendidikan dalam pandangan Islam.

Dasar pendidikan Islam adalah tauhid. Konsep tauhid menjadi tema yang sangat penting dalam pandangan Islam serta mengandung implikasi doktrinal yang berkaitan dengan tujuan hidup manusia haruslah dalam kerangka beribadah kepada Allah swt. Dokrin ini merupakan kunci dari seluruh ajaran Islam. Dari konsep tauhid inilah akan muncul standar yang sangat penting dalam konsep pendidikan Islam, yaitu satandar akhlak (baca: standar nilai), yang esensinya adalah baik-buruk. Konsep pendidikan berbasis tauhid ini sesungguhnya sudah

\footnotetext{
9 Departemen Agama RI, al-Qur'an dan Terjemahannya (Jakarta: Cipta Bagus Segara, 2012), 412.

10 Departemen Agama RI, al-Qur'an dan Terjemahannya, 523.

11 Departemen Agama RI, al-Qur'an dan Terjemahannya, 6.

12 Departemen Agama RI, al-Qur'an dan Terjemahannya, 203

${ }^{13}$ Departemen Agama RI, al-Qur'an dan Terjemahannya, 31.
} 
diajarkan oleh Allah swt., melalui seorang ahli hikmah yang namanya diabadikan sebagai salah satu nama surah dalam al-Qur'an, yaitu Luqman. Konsep pendidikan perspektif Luqman ialah menjadikan keimanan kepada Allah swt. (tauhid) sebagai pelajaran pertama.

Ayat tersebut menegaskan bahwa tauhid atau akidah sebagai basis pendidikan. Tauhid dijadikan sebagai fondasi atau dasar, sebab dari tauhid itulah aspek-aspek lain (ibadah dan akhlak) dilahirkan. Sedangkan dalam ayat-ayat berikutnya, barulah Luqman memberikan pelajaran akhlak dan ibadah kepada anaknya, seperti perintah untuk berbakti kepada orang tua, larangan untuk tidak sombong, perintah mendirikan shalat dan sebagainya. Dalam al-Qur'an, Allah membuat tamsil yang sangat indah mengenai ketiga aspek (akidah-ibadahakhlak).

Pendidikan Islam ialah pendidikan yang bertujuan untuk membentuk pribadi muslim seutuhnya, mengembangkan seluruh potensi baik yang berbentuk jasmaniah maupun rohaniah, menumbuhsuburkan hubungan yang harmonis setiap pribadi dengan Allah swt., manusia dan alam sekitar. Sehingga, aktivitas pendidikan Islam hendaknya diarahkan pada pembentukan karakter yang dapat melahirkan perilaku terpuji sebagai implikasi positif dari kegiatan pendidikan Islam yang dilaksanakan.

Dan di antara mereka ada orang yang bendoa: "Ya Tuhan Kami, berilah Kami kebaikan di dunia dan kebaikan di akhirat dan peliharalah Kami dari siksa neraka. Mereka Itulah orang-orang yang mendapat bahagian daripada yang mereka usahakan; dan Allah sangat cepat perhitungan-Nya." (QS. al-Baqarah: 201202). ${ }^{14}$

Selain beberapa tujuan pendidikan Islam di atas, Mutohar dan Anam menyatakan bahwa ada dua tujuan pendidikan Islam, yaitu tujuan umum dan tujuan khusus. Tujuan umum dari pendidikan Islam ialah untuk membentuk manusia dengan akhlak yang sempurna. Hal ini sejalan dengan misis kerasulan Nabi Muhammad saw., yakni menyempurnakan akhlak hingga menjadi mulia. Tujuan umum tersebut dirinci menjadi tujuan-tujaun khusus untuk pembinaan akhlak, menyiapkan anak didik untuk di dunia dan akhirat, penguasaan ilmu dan keterampilan bekerja dalam masyarakat. ${ }^{15}$ Sederhananya, tujuan umum pendidikan Islam adalah membina peserta didik agar menjadi hamba yang suka beribadah kepada Allah swt. Ibadah ini tidak hanya berarti ibadah-ibadah ritual yang bersifat vertikal (hubungan seorang hamba dengan Tuhan), tetapi mencakup juga ibadah sosial, yaitu ibadah yang bersifat horizontal (hubungan manusia dengan sesama manusia dan lingkungan sekitar).

14 Departemen Agama RI, al-Qur'an dan Terjemahannya, 31.

15 Ahmad Mutohar dan Nurul Anam, Manifesto: Modernisasi Pendidikan Islam \& Pesantren (Yogyakarta: Pustaka Pelajar, 2013), 53. 


\section{Masyarakat Petani di Kabupaten Pamekasan}

Secara definitif, petani adalah sebagian penduduk yang secara eksistensial terlibat dalam proses cocok tanam dan secara otonom menetapkan keputusan atas cocok tanam tersebut. Definisi tersebut menitikberatkan pada kegiatan seseorang secara nyata bercocok tanam. ${ }^{16}$ Dengan demikian, mencakup penggarapan dan penerimaan bagi hasil maupun pemilik, penggarap selama mereka berada pada posisi membuat keputusan yang relavan tentang bagaimana pertumbuhan tanaman mereka, namun tidak termasuk nelayan dan buruh tani yang tidak bertanah. Karena, petani merupakan semua orang yang yang menetap di daerah pedesaan yang mengelola usaha pertanian yang membedakan dengan masyarakat lainnya adalah faktor pemilikan tanah atau lahan yang dimilikinya.

Petani adalah setiap orang yang melakukan usaha untuk memenuhi sebagian atau seluruhnya kebutuhan kehidupan di bidang pertanian. Pada umumnya, pengetahuan petani itu terbatas, sehingga mengusahakan kebunnya secara tradisional. Terkadang kemampuan permodalannya juga terbatas dan bekerja dengan alat-alat sederhana. ${ }^{17}$ Dengan demikian, produktivitas dan produksinya yang sudah rendah itu akan lebih rendah lagi. Maka dari itu, berdasarkan pemaparan di atas, dapat penulis simpulkan bahwa petani adalah penduduk desa yang mata pencahariannya bercocok tanam dengan menggunakan teknologi yang sederhana dan dengan kesatuan produksi yang tidak terspesialisasi. Sehingga kehidupan petani bergantung pada alam sebagai tempat mencukupi kebutuhan pokok dalam kehidupannya.

Mosher, membagi pertanian pada dua golongan, yaitu pertanian primitif dan pertanian modern. Pertanian primitif diartikan sebagai petani yang bekerja mengikuti metode-metode yang berasal dari orang-orang tua dan tidak menerima pembaharuan (inovasi). Meraka yang mengharapkan bantuan alam untuk mengolah pertaniannya. Sedangkan pertanian modern adalah suatu pertanian yang menguasai pertumbuhan tanaman dan aktif mencari metode-metode baru serta serta dapat menerima pembaharuan (inovasi). Petani macam inilah yang dapat berkembang dalam rangka menunjang ekonomi baik di bidang pertanian maupun di bidang-bidang lainnya.

Ada beberapa petani jenis petani di Indonesia, yaitu: Pertama, petani gurem adalah petani kecil yang memiliki luas lahan 0,25 ha. Petani ini merupakan kelompok petani miskin yang memiliki sumber daya terbatas. Kedua, petani

16 Petani merupakan komunitas kecil yang memiliki beberapa karakteristik, yaitu: mempunyai identitas yang khas (distinctiveness), terdiri atas sejumlah penduduk dengan jumlah yang cukup terbatas (smallness) sehingga masih saling mengenal sebagai individu yang berkepribadian, bersifat seragam dengan deferensiasi terbatas (homogeinity) dan kebutuhan hidup penduduknya sangat terbatas sehingga semua dapat dipenuhi sendiri tanpa bergantung pada pasaran luar. Lihat Arif Satria, Pengantar Sosiologi Masyarakat Pesisir (Jakarta: Yayasan Pustaka Obor Indonesia, 2015), 12.

${ }^{17}$ Arfi Satria, Pengantar Sosiologi Masyarakat Pesisir, 13. 
modern adalah kelompok petani yang menggunakan teknologi dan memiliki orientasi keuntungan melalui pemanfaatan teknologi tersebut. apabila petani memiliki lahan 0,25 ha, tetapi pemanfaatan teknologinya baik, dapat juga dikatakan sebagai petani modern.Ketiga, petani primitif adalah petani-petani dahulu yang bergantung pada sumber daya dan kehidupan mereka berpindahpindah. ${ }^{18}$

Berdasarkan macam-macam petani tersebut, pertanian memiliki beberapa bentuk, yaitu sebagai berikut: Pertama, sawah, yaitu suatu bentuk pertanian yang dilakukan di lahan basah dan memerlukan banyak air baik sawah irigasi, sawah lbak, sawah tadah hujan maupun sawah pasang surut. Kedua, tegalan, yaitu suatu daerah dengan lahan kering yang bergantung pada pengairan air hujan, ditanami tanaman musiman atau tahunan dan terpisah dari lingkungan dalam sekitar rumah. Lahan tegalan tanahnya sulit untuk dibuat pengairan irigasi, karena permukaan yang tidak rata. Pada saat musim kemarau lahan tegalan akan kering dan sulit untuk ditumbuhi tanaman pertanian. Ketiga, ladang berpindah, yaitu suatu kegiatan pertanian yang dilakukan di banyak lahan hasil pembukaan hutan atau semak, dan setelah beberapa kali panen/ditanami, tanah tersebut sudah tidak subur lagi sehingga perlu pindah ke lahan lain atau lahan yang sudah lama tidak digarap. Keempat, tanaman keras, yaitu suatu jenis varietas pertanian yang jenis pertaniannya adalah tanaman-tanaman keras seperti karet, kelapa sawit dan cokelat.

Oleh karena itu, sebenarnya yang menjadi titik tekan dari petani itu adalah usaha taninya dan manusia sebagai anggota masyarakat. Hal ini menunjukkan bahwa selain sebagai petani, ia juga sebagai anggota yang tidak terlepas dari lingkungan sosialnya. Sehingga dengan latar belakang hidup sebagai petani, tidak dapat dipungkiri akan memiliki pandnagan yang berbeda dari masyarakat pada umumnya terhadap pendidikan Islam sebagai suatu proses perbaikan ke arah perbaikan, penguatan dan penyempurnaan semua potensi manusia demi terciptanya khalifah Allah fi al-ardh dengan kecerdasan intelektual yang tinggi, moralitas serta spiritual yang unggul. Sosok khalifah Allah fi al-ardh itu bisa terlahir dari seorang cendikia, para kiai maupun petani.

Menyoal pertanian di kabupaten Pamekasan, selain mempunyai misi memperluas pendidikan berbasis potensi daerah dan pemerataan kualitas

18 Jika dilihat dari sistempola tanam, ada dua pola tanam masyarakat petani saat ini ialah: Pertama, pola tanam monokultur dan multikultur, yaitu cara bercocok tanam yang dilakukan oleh para petani pada lahan sawah yang hanya ditanami satu jenis tanaman tertentu pada setiap musimnya. Walaupun demikian pada setiap pergantian musim tanam bisa ditanami dengan berbagai jenis tanaman berbeda. Kedua, pola tanam multiplecropping, yaitu cara bercocok tanam yang dilakukan oleh para petani pada suatu lahan sawah yang ditanami berbagai jenis tanaman dalam kurun waktu satu kali musim tanam. Pola tanam jenis ini merupakan pola tanam yang paling banyak dilakukan oleh petani yang memiliki lahan sempit. Lihat Fatchan dan Basrowi, Pembelotan Kaum Pesantren, 133-137. 
pendidikan, meningkatkan dan mengoptimalkan hidup bersih dan sehat melalui peningkatan fasilitas layanan kesehatan, dan mempercepat pembangunan infrastruktur publik, kabupaten Pamekasan juga memiliki misi utama yakni meningkatkan pembangunan bidang ekonomi dengan prioritas sektor pertanian dan optimalisasi komoditas unggulan daerah yang berwawasan lingkungan.

Kabupaten yang mendeklarasikan sebagai kabupaten pendidikan ini memiliki sector pertanian yang selalu mengalami peningkatan. Dengan luas areal pertanian Kabupaten Pamekasan keseluruhnya mencapai 74.467,167 Ha yang terdiri luas tegalan 62.013,769 Ha, sawah irigrasi 6.649,5 Ha dan sawah tadah hujan 5.803,898 Ha. Selain padi terdapat pula Beberapa komoditas untuk sayuran seperti bayam, kangkung, terong, bawang merah, lombok, kacang panjang, ketimun.

Sedangkan untuk tanaman holtikultura terdapat durian, jaruk, mangga dan pisang. areal persawahan yang paling banyak terdapat di Kecamatan Pademawu, Proppo, Pegantenan dan Palengaan, sedangkan kawasan tegalan yang banyak terdapat di kecamatan Pamekasan, Pademawu dan Proppo. Di sektor perkebunan, masyarakat kabupaten pamekasan memprioritaskan tanam tembakau sebagai mata pencarian utama di musim kemarau maupun daerah kering. Komoditas tanaman tembakau sebagian besar dipasarkan pada pasar regional, nasional maupun internasional Khususnya pada pabrik rokok (Gudang garam, Sampurna, Djarum, dan lain-lain). Hal ini tembakau Pamekasan citra rasa tersendiri dan biasanya digunakan sebagai bahan campuran dari tembakau yang ada di tempat lain.

\section{Pendidikan Islam Perspektif Petani di Pamekasan}

Pendidikan Islam merupakan hal penting dalam kehidupan manusia. Karena pendidikan Islam merupakan pendidikan yang berbasis Islam yang akan membentuk kehidupan manusia sesuai dengan nilai-nilai Islam. Bagi masyarakat Pamekasan, di samping pentingnya pendidikan Islam, juga terdapat makna pendidikan Islam yaitu sebuah usaha sadar dan disengaja yang dilakukan untuk membimbing seseorang berdasarkan nilai-nilai keislaman agar menjadi pribadi yang baik dan menjadi insan kamil yang dapat memelihara hubungannya terhadap Allah SWT, sesama manusia, dirinya sendiri dan terhadap lingkungan sekitarnya.

Adapun pendidikan Islam menurut pandangan para petani garam di Kecamatan pademawu sebagaimana wawancara dengan salah seorang petani yang menyatakan bahwa: "Pendidikan Islam engghi panèka sèttong cara adidik otabâ ngajâri masala-masala aghâma ḍa'ana' didik (Pendidikan Islam merupakan 
sebuah upaya mendidik atau mengajarkan ajaran-ajaran Islam kepada anak didik)" ${ }^{19}$

Pendapat tersebut di atas juga sesuai dengan pernyataan Ernawati sebagaimana petikan wawancara berikut: "Pendidikan Islam panèka sèttong pangajârân ḍâ' kaulâ sadhâjâ sè bậ̣̂̂ hubunganna kalabân aghâma Islam bân bhisa ngajâri kita sopajâ kalakowan kaulâ sadhâjâ ta' kalowar ḍ̂ri syari'at Islam (Pendidikan Islam itu sebuah pengajaran kepada kita yang memiliki kandungan keislaman dan bisa mengajarkan kita agar selalu bertindak sesuai syari'at Islam)".20

Pernyataan Ernawati juga sesuai dengan pendapat yang disampaikan oleh Bapak Ismail yang menyatakan bahwa: "Pendidikan Islam panèka yâ pendidikan sè bhâgus. Kaulâ korang ngaunèngi kalabân cè' lèrressa, coma kaulâ onèng dâri kalakoan rè-sa'arè, engghi ka'ḍinto ngajâri ana' sopajâ andị' tèngka lako sè bhâgus (Pendidikan Islam itu ya pendidikan yang bagus dan baik. Saya kurang memahami secara detail, hanya saya pahami melalui perilaku sehari-hari, yaitu mengajari anak-anak untuk berakhlak yang baik)". ${ }^{21}$

Hal senada juga sesuai dengan pernyataan salah seorang petani yang menyatakan bahwa: "Metorot pamahaman kaulâ, pendidikan akhlak sè saè dâlèm bân-sabbân ana' bân manussa sè laèn sopajâ kita ngaghungi tengka lako sè lèrres sami sarèng ajârân aghâma Islam (Menurut sepemahaman saya, penanaman akhlak yang baik dalam diri anak didik dan manusia lainnya agar mereka tetap berbuat dan bertingkah laku sesuai dengan ajaran Islam yang ada)".22

Hal senada juga sesuai dengan pernyataan Ibu Khairiyah yang menyatakan bahwa: "Manabi metorot kaulâ, adidik sè sami sarèng ajhârân Islam. Kaulâ ta' bhisa ajèllassaghi kalabân loas, ghun coma kaulâ ngamallaghi pendidikan Islam ḍ̂' keloarghâ èngghi panèka abimbing akhlak sè bhâgus (Kalau menurut saya, mendidik sesuai ajaran Islam. Saya kurang begitu bisa menjelaskan secara luas, hanya saja saya mengaplikasikan pendidikan Islam kepada keluarga saya yakni menanamkan akhlak yang baik bagi mereka)". ${ }^{23}$

Dari beberapa hasil wanwancara dengan petani garam di atas, dapat dipahami bahwa makna pendidikan Islam menurut petani garam ialah sebuah upaya memberikan pendidikan dan pengajaran yang berbasis Islam kepada

19 Moh. Roqib, Warga Desa Padeleggan Kecamatan Pademawu, Petani Garam, Wawancara Langsung (01 Maret 2018).

${ }^{20}$ Ernawati, Warga Desa Padeleggan Kecamatan Pademawu, Anak Petani Garam, Wawancara Langsung (01 Maret 2018).

${ }^{21}$ Ismail, Warga Desa Padeleggan Kecamatan Pademawu, Petani Garam, Wawancara Langsung (05 Maret 2018).

22 Misnawi, Warga Desa Padeleggan Kecamatan Pademawu, Petani Garam, Wawancara Langsung (05 Maret 2018).

${ }^{23}$ Khairiyah, Warga Desa Padeleggan Kecamatan Pademawu, Ibu Rumah Tangga dan Petani Garam, Wawancara Langsung (09 Maret 2018). 
peserta didik guna membentuk pribadi yang baik serta penanaman akhlak yang terpuji dalam kehidupan sehari-hari sejalan dengan syari'at Islam.

Sementara dalam perspektif petani padi, disampaikan oleh salah seorang anak dari petani padi di Kecamatan Galis yang menyatakan bahwa: "Pendidikan Islam panèka pendidikan sè aḍ̂asar Islam sopajâ ngara'aghi manussa khusus èpon ana' sopajâ dhâddhi ana' sè ngaghungi tèngka sè bhâgus(Pendidikan islam itu merupakan sebuah pendidikan yang berbasis Islam untuk mengarahkan manusia khususnya seorang anak agar menjadi anak yang memiliki kepribadian yang lebih baik)". ${ }^{24}$

Hal senada juga disampaikan oleh Bapak Ahmad Baidawi yang menyatakan bahwa: "Kaulâ ngartè'aghi proses adidik ana' sè sami sarèng ajhârân Islam. Engghi ka'dinto abimbing metorot ajhârân Islam, alatè, ngasuh, maènga' manabi alako kasala'an sè nyimpang ḍ̂ri syari'at Islam(Saya artikan sebagai sebuah proses mendidik anak sesuai dengan ajaran Islam. Yaitu dibimbing menurut ajaran islam, melatih, mengasuh, mengingatkan jika melakukan kesalahan yang melanggar syari'at Islam)". ${ }^{25}$

Ungkapan Bapak Ahmad Baidawi juga sesuai dengan pernyataan petani padi lainnya, sebagaimana petikan wawancara berikut: "Pendidikan Islam panèka proses nanemmaghi nilai-nilai kabhâgusan ḍ̂ $\hat{a}^{\prime} k a$ ana' lèbât tèngka lako rèsaarèdâlèm kalowarghâ tor masyarakat, è roma, è sakolaan bân è lingkungan sekitar(Pendidikan Islam itu proses menanamkan nilai-nilai kebaikan pada anak melalui aplikasi sehari-hari dalam keluarga maupun dalam bermasyarakat, baik itu di rumah, sekolah dan lingkungan sekitar kita bermukim)". ${ }^{26}$

Ungkapan tersebut di atas juga sesuai dengan pernyataan Ibu Nur yang menyatakan bahwa: "Sè kaulâ pahami ka'dissa' engghi tèngka lako sè bhâgus sè sami sarèng atoran-atoran Islam sè bhâkal adhâddhiyâghi kita mènangka umat manussa sè ngaghungi bhâbhâtèk sè bhâgus(Yang saya pahami itu ya perilakuperilaku yang terpuji yang mana sesuai dengan aturan-aturan Islam yang akan menjadikan kita sebagai umat manusia yang memiliki pribadi yang baik)". ${ }^{27}$

Hal senada juga sesuai dengan ungkapan Bapak Tifa yang menyatakan bahwa: "Kaulâ korang onèng sè ajèllasaghiyâ kalabân sanget rinci, ghun coma sè kaulâ pahami engghi panèka sèttong pangajhârân sè sami sarèng ajhârân Islam sopajâ bhisa nyèpta ana' sè ngaghungi akhlak bhâgus tor bhâbhâtèk se saè(Saya kurang begitu bisa menjelaskan dengan sangat rinci, hanya yang saya pahami itu

24 Fatimah, Warga Desa Galis Kecamatan Galis, Anak Petani Padi, di Rumah Kediaman, Wawancara Langsung (11 Maret 2018).

25 Ahmad Baidawi, Warga Desa Galis Kecamatan Galis, Petani Padi, di Sawah, Wawancara Langsung (11 Maret 2018).

${ }^{26}$ Munahir, Warga Desa Galis Kecamatan Galis, Petani Padi, di Sawah, Wawancara Langsung (15 Maret 2018).

27 Nur, Warga Desa Galis Kecamatan Galis, Petani Padi, di Sawah, Wawancara Langsung (18 Maret 2018). 
adalah sebuah pengajaran yang sesuai dengan ajaran Islam guna mewujudkan anak yang berakhlak mulia dan berkepribadian yang bagus)". ${ }^{28}$

Berdasarkan hasil wawancara dengan petani padi di Pamekasan, dapat disimpulkan bahwa pentingnya pendidikan Islam menurut petani padi adalah sebuah pendidikan dan pengajaran yang berbasis Islam untuk mengarahkan manusia dalam membentuk pribadi yang lebih baik melalui pengaplikasian sikap dan perilaku kehidupan sehari-hari baik dalam kehidupan keluarga maupun dalam kehidupan bermasyarakat.

Selanjutnya, pendapat tentang makna pendidikan Islam juga dinyatakan oleh petani tembakau di Kecamatan Pakong yang menyatakan bahwa: "Pendidikan Islam panèka bimbingan sè sami sarèng syari'at Islam ḍ̂' ka manussa khusus èpon ana'-ana' sopajâ ana'-ana' $t a^{\prime}$ alako sè $t a^{\prime}$ bhèndhèr(Pendidikan Islam itu merupakan bimbingan bagi manusia khususnya anak-anak sesuai dengan syari'at Islam agar anak-anak tidak terjerumus pada hal-hal yang tidak baik)" ${ }^{29}$

Pernyataan tersebut di atas juga sesuai dengan ungkapan petani lainnya, sebagaimana petikan wawancara berikut: "Pendidikan Islam panèka metorot kaulâ sèttongkalakoan kaangghuy aparèng pangajhârân-pangajhârân aghâma sèdègghi' bhâkal dhâddhi tatèkghu'ân oḍi' ḍ̂lèm kaoḍi'ân rè-saarè tentang tèngka lako(Pendidikan Islam itu menurut saya sebuah upaya untuk memberikan pengajaran-pengajaran agama yang nantinya akan menjadi pegangan hidup dalam kehidupan sehari-hari mengenai bertingkah laku dan bersikap)".30

Ungkapan tentang pentingnya pendidikan Islam juga disampaikan oleh Ahmadi, sebagaimana petikan wawancara berikut: "Yâ proses aobâna tèngka lako sèttong orèng sè kodhu ậ̣asar Islam. Sopajâ manussa anḍi' tèngka lako sè ta' ngontongngaghi ḍ̂a' ka bâ' dhibi'na, tèrro mènnangnga dhibi' tanpa kodhu apèkkèr akibât bhâgus otabâ jhubâ'na(Ya proses pengubahan sikap dan tingkah laku seseorang yang harus berbasis ajaran Islam. Supaya mereka nantinya bertingkah tidak seenaknya sendiri, mau menang sendiri tanpa harus berpikir apa dampak bagus dan jeleknya)". 31

Hal senada juga sesuai dengan pernyataan petani lainnya yang menyatakan bahwa: "Pastèna pangajhârân sè bâdâ nilai-nilai Islamma. Akadhiyâ, sholat, ngaji, atèngka sè bhâgus ḍ̂a' ka bâlâ tatanggâ è ka'ḍinto. Karna kaulâ korang bhisa ajèllassaghi akadhi orèng-orèng s2 dhâddhi ghuru(Pastinya pengajaran yang mengandung nilai-nilai Islam. Seperti shalat, mengaji, bersikap ramah kepada

28 Tifa, Warga Desa Galis Kecamatan Galis, Petani Padi, di Sawah, Wawancara Langsung (18 Maret 2018).

${ }^{29}$ Ruqayyah, Warga Desa Seddur Kecamatan Pakong, Petani Tembakau, di Rumah Kediaman, Wawancara Langsung (25 Maret 2018).

${ }^{30}$ Musyrifah, Warga Desa Seddur Kecamatan Pakong, Petani Tembakau, di Rumah Kediaman, Wawancara Langsung (28 Maret 2018).

31 Ahmadi, Warga Desa Seddur Kecamatan Pakong, Petani Tembakau, di Rumah Kediaman, Wawancara Langsung (28 Maret 2018). 
sesama warga di sini. Karena saya kurang bisa menjelaskan secara detail dan jelas seperti orang-orang yang menjadi guru)".32

Pernyataan tersebut di atas juga sesuai dengan ungkapan Ibu Sitti Halimatus Sakdiyah tentang pentingnya pendidikan Islam, sebagaimana petikan wawancara berikut: "Pendidikan Islam engghi panèka usaha ngob engghi tèngka lako sèttong orèng sopajâ dhâddhi lèbbih bhâgus sajhâlân sarèng syari'at Islam. Saèngghâ dhâddhi ana' sè sholeh tor sholehah(Pendidikan Islam itu ya usaha dan upaya perubahan sikap dalam diri seseorang menjadi lebih baik sesuai dengan syari'at Islam. Sehingga menjadi anak yang sholeh dan sholehah)”. 33

Dari pemaparan beberapa petani tembakau di Kabupaten Pamekasan, dapat ditarik benag merah bahwa urgensi pendidikan Islam menurut petani tembakau adalah upaya memberikan bimbingan dan pengajaran agama serta pola pengubahan sikap dan tingkah laku seseorang yang berbasis Islam menuju terbentuknya pribadi manusia yang taat pada syari'at Islam.

Hasil wawancara mengenai pendapat para petani tentang pendidikan Islam diperkuat dengan observasi bahwasanya tampak para petani antusias dengan pendidikan anak-anaknya, di antaranya yaitu memberangkatkan anaknya ke pondok pesantren hingga ke perguruan tinggi. Selain melalui pengamatan, hal tersebut di atas juga diperkuat dengan dokumentasi bahwa tampak beberapa foto pendidikan dari anak para petani yang terpampang di dinding rumah mereka.

\section{E. Pemaknaan Pendidikan Islam Perspektif Petani di Pamekasan}

Secara umum, makna pendidikan Islam dalam perspektif petani baik petani garam, padi dan tembakau memiliki kesamaan terutama dari segi tujuan yang hendak dicapai dari proses yang dilakukan yaitu untuk membentuk pribadi denganakhlak yang baik baik kepada Tuhan, sesama manusia maupun alam semesta. Maka dari itu, aplikasi pendidikan Islam dalam kehidupan sehari-hari hendaknya dijalankan dengan baik agar tujuan mulia tersebut dapat tercapai dengan baik. Perlu ditegaskan bahwa pendidikan merupakan bagian yang tak terpisahkan dari hidup dan kehidupan manusia, dan lembaga pendidikan pertama bagi setiap manusia adalah keluarga. Di sanalah anak mengawali interaksinya dengan lingkungan sekitar, terutama orang tua. ${ }^{34}$ Maka, pendidikan agama Islam pada anak dalam keluarga merupakan hal yang urgen karena menyangkut internalisasi nilai-nilai religius sebagai upaya menjaga potensi fitrah yang dibawanya sejak lahir.

32 Busahwi, Warga Desa Seddur Kecamatan Pakong, Petani Tembakau, di Rumah Kediaman, Wawancara Langsung (31 Maret 2018).

${ }^{33}$ Sitti Halimatus Sakdiyah, Warga Desa Seddur Kecamatan Pakong, Petani Tembakau, di Rumah Kediaman, Wawancara Langsung (31 Maret 2018).

34 Jalaluddin, Teologi Pendidikan, 68. 
Internalisasi nilai-nilai seharusnya memang dimulai dari lingkungan keluarga sebagai lembaga pendidikan yang paling dekat dengan anak. Pandangan dan sikap orang tua terhadap anak dalam hal tersebut sangat dipengaruhi oleh pemahamannya terhadap agama itu sendiri. Pemahaman yang benar akan menghasilkan pandangan dan sikap yang benar dalam mendidik anak, begitu juga sebaliknya. Sebab pendidikan agama Islam merupakan pendidikan yang mengarahkan anak didik pada perilaku-perilaku terpuji sesuai dengan ajaranajaran Islam.

Keluarga merupakan unit sosial terkecil yang memiliki peran penting dalam pengembangan karakter anak. Namun, penyelenggaraan pendidikan karakter dalam lingkungan keluarga secara operasional maupun prosedural, belum menjadi perhatian serius para orang tua dan cenderung diabaikan. Akibatnya, pendidikan karakter pada anak dalam keluarga belum dikonseptualisasikan secara ajeg sehingga menimbulkan praksis pendidikan yang beragam sesuai dengan pemahaman masing-masing orang tua. ${ }^{35}$ Oleh karena itu, dibutuhkan kerangka model yang ajeg dan rinci untuk dapat melaksanakan pendidikan karakter dalam keluarga secara tepat dan sesuai dengan pedagogis Islami.

Terkait dengan pelaksanaan pendidikan Islam yang dilakukan oleh petani garam di Pamekasan Madura di antaranya yaitu memberangkatkan anak-anaknya ke langgar untuk mengaji, shalat dan belajar keagamaan, membimbing dan menasehati anak-anaknya untuk selalu berbuat baik kepada orang lain, berbakti kepada kedua orang tua serta mengingatkan untuk shalat dan belajar. Sedangkan pelaksanaan pendidikan Islam yang dilakukan oleh petani padi khususnya di Pamekasan Madura diantaranya yaitu memberikan contoh yang baik dalam berperilaku dan bergaul kepada orang lain atau teman-teman sebayanya, memberangkatkan anak-anaknya ke langgar untuk mengaji, mengaji di rumah masing-masing dengan mendatangkan guru mengaji, menyambung tali silaturrahìm, saling bergotong royong, dan tolong menolong.

Sementara pelaksanaan pendidikan Islam yang dilakukan oleh para petani tembakau tepatnya di pamekasan Madura diantaranya yaitu menyerahkan anakanaknya untuk mengaji dan belajar keagamaan di langgar, mengajarkan anakanaknya untuk bersikap sopan santun, dan berbakti kepada kedua orang tuanya. Pelaksanaan pendidikan sebagaimana diungkapkan oleh para petani baik garam, padi maupun tembakau tidak jauh berbeda secara garis besar mereka memahami pelaksanaan pendidikan Islam hanya sebatas peran orang tua dalam mengingatkan anak ketika melakukan suatu kesalahan, menyuruh anak mengaji ke langgar, menyuruh anak belajar dengan rajin ada pula yang memondokkan

35 Amirulloh Syarbini, Pendidikan Karakter Berbasis Keluarga: Studi tentang Model Pendidikan Karakter dalam Keluarga Perspektif Islam (Jogjakarta: ar-Ruzz Media, 2016), 7. 
anaknya ke suatu pondok pesantren agar pemahaman keagamaannya semakin dalam. Sehingga, tanggung jawab pendidikan dalam lingkungan keluarga hanya berkisar pada hal-hal tersebut.

Proses pendidikan dalam keluarga, dilakukan dengan mengkoordinasi sejumlah komponen pendidikan agar satu sama lain saling berkaitan dan mempengaruhi sehingga menumbuhkan kegiatan pendidikan yang efektif menuju terjadinya perubahan tingkah laku anak sesuai dengan tujuan yang diharapkan. Dalam hal ini, orang tua sebagai pendidik dalam keluarga mengajarkan materi pendidikan dan menginternalisasikan nilai-nilai yang menjadi acuan setiap perilaku.36 Hal itu kemudian dilanjutkan oleh lembaga pendidikan yang lain. Sehingga, pendidikan agama Islam pada anak dilakukan secara bertahap.

Sejatinya, peran orang tua di lingkungan keluarga dalam perspektif Islam, tidak hanya dicukupkan dengan memenuhi segala kebutuhan material anak, tetapi yang terpenting ialah pendidikan anak, sebuah bagian tanggungjawab nonmaterial. Hal itu dapat dilakukan dengan memberikan teladan sikap, membimbing, menasihati serta mengingatkan anak untuk membiasakan diri melakukan kebaikan-kebaikan dalam kehidupan sehari-hari, sebagai upaya internalisasi. Menempatkan tanggung jawab dengan jujur adalah contoh proses internalisasi nilai-nilai islami yang dilakukan orang tua pada anak dalam lingkungan keluarga. ${ }^{37}$

Kesadaran orang tua akan hal tersebut menjadi taruhan dalam keberhasilan penanaman nilai-nilai keagamaan pada diri anak atau kesalehan anak dalam beragama. Agama merupakan pondasi hidup yang harus dimiliki sebagai wasilah bagi semua bangsa untuk menemukan keteraturan, kedamaian dan kebenaran. Urgensitas agama dalam kehidupan manusia menjadi suatu petanda bahwa pendidikan agama merupakan kewajiban asasi setiap orang tua yang mesti ditunaikan sebaik-baiknya, meskipun banyak diantara mereka yang telah gagal melaksanakannya. Kualitas rohani dan moral anak yang semakin mengalami krisis di berbagai tempat beberapa tahun terakhir adalah bukti kegagalan mereka sebagai orang tua.Hal ini tentu bermula dari pandangan dan tindakan yang yang salah dalam mendidik anak.

Namun, tidak dapat dipungkiri bahwa orang tua tetap merupakan sosok insan yang paling berjasa pada setiap anak. Sejak awal kelahirannya, anak bergantung sepenuhnya kepada orang tuanya, termasuk dalam hal pendidikan. Peran orang tua terhadap pendidikan anak bukan sekedar sebagai kewajiban, melainkan menjadi sebuah kebutuhan untuk meneguhkan eksistensinya sebagai makhluk Tuhan yang bersih dari segala bentuk kesyirikan dan ketergantungan kepada selainNya. Oleh karena jasa-jasa yang begitu banyak dan bernilai, orang

${ }^{36}$ Amirulloh Syarbini, "Pendidikan Karakter Berbasis Keluarga," 206.

${ }^{37}$ Mohamad Mustari, Nilai Karakter: Refleksi untuk Pendidikan (Jakarta: Rajawali Pers, 2014), 5. 
tua dalam ajaran Islam memiliki posisi yang terhormat dan mulia. Orang tua memiliki hak untuk dihormati oleh anak-anak, begitupun sebaliknya anak-anak memiliki hak untuk mendapatkan pendidikan yang sebaik-baiknya dari orang tua. Karena orang tua dalam lingkungan keluarga merupakan lembaga pendidikan pertama dan utama bagi anak.

Kedisiplinan dalam keluarga terwujud dari kebiasaan yang ditampakkan oleh orang tua dalam kehidupan sehari-hari. Burdah mengungkapkan bahwa membiasakan anak untuk menegakkan kedisiplinan, seperti halnya bangun setiap pagi, shalat tepat waktu, menemani anak mengerjakan tugas-tugas sekolah dengan baik serta mengajari anak untuk ikut membantu pekerjaan rumah (menyapu, merapikan tempat tidur dan lain-lain), merupakan hal kecil yang memiliki pengaruh besar terhadap kehidupannya.38 Dalam prinsip pembiasaan diperlukan keteladanan orang tua untuk mewujudkan pribadi anak sesuai yang diharapkan.

\section{F. Kesimpulan}

Pendidikan Islam dalam perspektif petani di Pamekasan Madura dianggap sebagai upaya memberikan pendidikan dan pengajaran serta pola pengubahan sikap dan tingkah laku seseorang yang berbasis Islam untuk mengarahkan manusia dalam membentuk pribadi yang lebih baik melalui pengaplikasian sikap dan perilaku kehidupan sehari-hari, baik dalam kehidupan keluarga maupun masyarakat. Pelaksanaan pendidikan Islam yang dilakukan oleh para petani di Pamekasan yaitu memberangkatkan anak ke langgar untuk mengaji, shalat dan belajar keagamaan, membimbing dan menasehati anak untuk selalu berbuat baik kepada orang lain, berbakti kepada kedua orang tua serta mengingatkan untuk shalat dan belajar. Tidak dapat dipungkiri bahwa peran orang tua dalam pelaksanaan pendidikan Islam pada kehidupan petani (garam, padi dan tembakau) di Pamekasan Madura yaitu sebagai pemberi nasehat dan semangat kepada anak-anaknya, lebih menanamkan akhlak pada anak, memberi suri tauladan kepada anak, dan memberi dorongan moril menuju terbentuknya pribadi yang baik. Hal ini menandakan bahwa konstruksi sosial memiliki pengaruh terhadap pertumbuhan dan perkembangan anak pada setiap fasenya. Oleh sebab itu, pola asuh yang baik dari orang tua dan sikap positif lingkungan serta penerimaan masyarakat terhadap keberadaan anak akan menumbuhkan konsep diri positif bagi anak dalam menilai diri sendiri. Motivasi kewajiban moral sebagai konsekuensi kedudukan orang tua terhadap keturunannya merupakan tanggung jawab moral yang meliputi nilai-nilai religius spiritual.

38 Ibnu Burdah, Pendidikan Karakter Islami (Jakarta: Erlangga, 2013), 23. 


\section{G. Referensi}

Achmadi. Ideologi Pendidikan Islam: Paradigma Humanisme Teosentris. Yogyakarta: Pustaka Pelajar, 2010.

Akhdiyat, Beni Ahmad Saebani dan Hendra. Ilmu Pendidikan Islam. Bandung: Pustaka Setia, 2012.

Albarobis, Sutrisno dan Muhyidin. Pendidikan Islam Berbasis Problem Sosial. Jogjakarta: Ar-Ruzz Media, 2012.

Anam, Ahmad Mutohar dan Nurul. Manifesto: Modernisasi Pendidikan Islam \& Pesantren. Yogyakarta: Pustaka Pelajar, 2013.

Basrowi, Fatchan dan. Pembelotan Kaum Pesantren dan Petani di Jawa. Surabaya: Yayasan Kampusina, 2004.

Burdah, Ibnu. Pendidikan Karakter Islami. Jakarta: Erlangga, 2013.

Jalaluddin. Teologi Pendidikan. Jakarta: Raja Grafindo Persada, 2003.

Mustari, Mohamad. Nilai Karakter: Refleksi untuk Pendidikan. Jakarta: Rajawali Pers, 2014.

RI, Departemen Agama. al-Qur'an dan Terjemahannya. Jakarta: Cipta Bagus Segara, 2012.

Roqib, Moh. Ilmu Pendidikan Islam: Pengembangan Pendidikan Integratif di Sekolah, Keluarga dan Masyarakat. Yogyakarta: LKiS, 2009.

Satria, Arif. Pengantar Sosiologi Masyarakat Pesisir. Jakarta: Yayasan Pustaka Obor Indonesia, 2015.

Siswanto. Filsafat dan Pemikiran Pendidikan Islam. Surabaya: Pena Salsabila, 2015.

Syarbini, Amirulloh. Pendidikan Karakter Berbasis Keluarga: Studi tentang Model Pendidikan Karakter dalam Keluarga Perspektif Islam. Jogjakarta: ar-Ruzz Media, 2016.

Ahmadi. Wawancara Langsung Petani Tembakau (Maret 28, 2018).

Baidawi, Ahmad. Wawancara Langsung Petani Padi (Maret 11, 2018).

Busahwi. Wawancara Langsung Petani Tembakau (Maret 31, 2018).

Ernawati. Wawancara Langsung Anak Petani Garam (Maret 01, 2018).

Fatimah. Wawancara Langsung Anak Petani Padi (Maret 11, 2018).

Ismail. Wawancara Langsung Petani Garam (Maret 05, 2018).

Khairiyah. Wawancara Langsung Ibu Rumah Tangga dan Petani Garam (Maret 09, 2018).

Misnawi. Wawancara Langsung Petani Garam (Maret 05, 2018). 
Munahir. Wawancara Langsung Petani Padi (Maret 15, 2018).

Musyrifah. Wawancara Langsung Petani Tembakau (Maret 28, 2018).

Nur. Wawancara Langsung Petani Padi (Maret 18, 2018).

Roqib, Moh.. Wawancara Langsung Petani Garam (Maret 01, 2018).

Ruqayyah. Wawancara Langsung Petani Tembakau (Maret 25, 2018).

Sakdiyah, Sitti Halimatus. Wawancara Langsung Petani Tembakau (Maret 31, 2018).

Tifa. Wawancara Langsung Petani Padi (Maret 18, 2018). 